\title{
Judgments Convention: Application to Governments
}

\author{
Paul R. Beaumont ${ }^{1}$ \\ Published online: 1 April 2020 \\ (C) The Author(s) 2020
}

\begin{abstract}
The Hague Judgments Convention 2019 makes the classic distinction between private law matters within its scope (civil or commercial matters) and public law matters outside its scope. It also follows the same position in relation to State immunity used in the Hague Choice of Court Convention 2005 (see Art. 2(5) in 2019 and 2(6) in 2005). The innovative parts of the 2019 Convention relate to the exclusions from scope in Article 2 relating to the armed forces, law enforcement activities and unilateral debt restructuring. Finally, in Article 19, the Convention creates a new declaration system permitting States to widen the exclusion from scope to some private law judgments concerning a State, or a State agency or a natural person acting for the State or a Government agency. This article gives guidance on the correct Treaty interpretation of all these matters taking full account of the work of the Hague Informal Working Group dealing with the application of the Convention to Governments and the other relevant supplementary means of interpretation referred to in Article 32 of the Vienna Convention on the Law of Treaties.
\end{abstract}

Keywords Civil or commercial matters $\cdot$ Public law $\cdot$ Armed forces $\cdot$ Law enforcement agencies · Unilateral sovereign debt restructuring $\cdot$ State immunity Declarations $\cdot$ Reciprocity

\footnotetext{
Paul Beaumont was a member of the EU delegation throughout the negotiations for the 2019 Judgments Convention (including the Working Group, the Special Commissions and the Diplomatic Session). He had previously been a member of the UK delegation in the unsuccessful negotiations of the original Judgments Project between 1996 and 2001 and for the successful negotiations on the Hague Choice of Court Convention 2005 from 2002 to 2005. During the work on the 2019 Judgments Convention Paul Beaumont was the Chair of the Informal Working Group dealing with the application of the Convention to Governments. It met during the Special Commission and in its final composition prior to the Diplomatic Session in Hong Kong, China in February 2019 and at the Diplomatic Session in The Hague in June 2019. Any views expressed in this article are personal to the author and may not reflect the views of the EU, UK, or any other State or international institution.
}

Paul R. Beaumont

paul.beaumont@stir.ac.uk

1 Professor of Private International Law, University of Stirling, Stirling, UK 


\section{Introduction}

As is often the case with Hague Conventions, the latest Hague Convention of 2 July 2019 (the Judgments Convention) only applies to 'civil or commercial matters'. Therefore, it only applies to judgments relating to a private law matter not to a public law matter. The restriction of the Convention to civil or commercial matters was never controversial throughout the negotiations. What was more controversial was how some States might interpret that restriction. Some States were concerned that what they would regard as a public law matter falling outside the scope of the Convention might be regarded by another State as a civil or commercial matter falling within the scope of the Convention. Of course, those States were aware that the Convention only becomes operative when a judgment from a Contracting State is sought to be recognised or enforced in another Contracting State. Therefore, the concerned States could become Contracting States to the Convention and still control, at least to some extent bearing in mind the independence of the judiciary, which judgments are recognised or enforced in their country. They could classify a foreign judgment as a public law judgment and therefore outside the scope of the Convention even if the court of the State of origin had classified it as a civil or commercial matter. However, this was not enough for those States for three reasons.

First, they respected the independence of their judiciaries and therefore knew that their judges might classify a foreign judgment as a civil or commercial matter even in cases where the current Government of the State might define the judgment as a public law matter outside the scope of the Convention. Those States with a dualist approach to treaty law could reduce that risk by implementing legislation defining for their courts what falls outside 'civil or commercial matters' for the purpose of the Convention. However, such a solution might not be consistent with their approach to implementing treaties or might not be accepted by their Parliaments when passing the implementing legislation. In monist States such an attempt to define the meaning of undefined provisions in a Treaty may not be legally possible.

Second, some of those States accepted the idea of a uniform treaty interpretation of the concept of 'civil or commercial matters' and therefore recognised that their more limited understanding of that concept might not prevail as the correct interpretation of the Treaty (especially since the trend is away from very broad notions of public law whenever the State or one of its agents is involved in litigation). So they wanted to give themselves as States the room to make a declaration to disapply the Convention to some of those 'civil or commercial matters'. In particular, when the State, or one of its State agencies, or a natural person acting for that State or one of its State agencies was a party to the proceedings that led to the foreign judgment that is sought to be enforced in the declaring State. Other States were reluctant to concede such a declaration system because they thought

\footnotetext{
${ }^{1}$ The full text of the Hague Judgments Convention is available at https://www.hcch.net/en/instruments/ conventions/full-text/?cid=137 (accessed 28 January 2020).

See also the Hague Conventions on Service (1965), Taking of Evidence (1970) and Choice of Court (2005).
} 
that from a policy point of view all private law matters (including those involving a State, or one of its agencies or a natural person acting for the State, or a State agency, whenever the State, etc. was not exercising any special powers) should be covered by the Convention. However, they were mindful of the fact that the Chair of the negotiations, David Goddard, had ruled on several occasions that there had to be a consensus to impose obligations on States under the Convention. Therefore, if there was no consensus to accept that foreign judgments concerning all 'civil or commercial matters' - apart from those specifically excluded by Article 2-would be governed by the Convention then the only alternatives were further exclusions from scope in Article 2 (applying to all States), a change to the provisions relating to States and their immunity in Articles 2(4) and (5), and a declaration system allowing some States to exclude certain matters.

Third, some States wanted clarity that certain issues would be outside the scope of the Convention even if most, if not all, such cases would be regarded as falling outside a uniform interpretation of 'civil or commercial matters' anyway. The Diplomatic Session focused on three such issues that were ultimately excluded in Article $2(1)(n),(o)$ and $(q)$.

Near the end of the Diplomatic Session it became clear that in order to keep the specific exclusions from scope in Article 2 that relate to States down to a minimum (i.e. that which is not too far away from the uniform interpretation of 'civil or commercial matters') it would be necessary to concede a declaration system to satisfy the small minority of States that insisted upon it. Some States with a concern about a restrictive approach to State immunity wanted to reopen the delicate balance on State immunity issues created by Article 2(4) and (5) - wholly taken over from the Hague Choice of Court Convention 2005. The Diplomatic Session avoided the difficult task of reopening the Article 2(4) and (5) provisions-which risked creating an a contrario interpretation with Hague Choice of Court 2005-or even of agreeing specific language for the explanatory report on those paragraphs, partly by conceding the declaration system found in Article 19. Partly this was done by building mutual trust in the negotiators working together in the Informal Working Group on Governments and sometimes due to that trust having been developed by long term interaction of negotiators over several Hague projects. Those States were also reassured that in the Judgments Convention the operative part of the Convention is only in the recognising and enforcing State (whereas the 2005 Convention has operative provisions for the court chosen and the court seised at the jurisdiction stage as well as provisions at the recognition and enforcement stage) and therefore their view of State immunity clearly prevails in the key operative provisions of the Convention due to the terms of Article 2(5). Admittedly those States run the risk that a judgment in another Contracting State against them or one of their agents might be recognised and enforced in a third Contracting State against their view that they had immunity. However, this possibility exists even without a Convention. To go further and try to make absolute State immunity, or something close to it, the agreed norm under the Convention would have been unacceptable to the majority of States and therefore could have blocked obtaining a Convention by consensus. The statesmanlike (or stateswomanlike) approach of the States favouring absolute State immunity (or a variation on that theme) - notably Argentina and Russia-in not insisting on the 
reopening of the Article 2(4) and (5) compromise or blocking a Convention containing that compromise was an important key to the success of the Convention.

\section{Treaty Interpretation}

When users of the Judgments Convention want to understand its meaning the natural starting point is the customary international law on treaty interpretation found in Articles 31 and 32 of the Vienna Convention on the Law of Treaties. ${ }^{2}$ The relevant parts of those Articles for interpreting the Judgments Convention are as follows:

\section{Article 31. GENERAL RULE OF INTERPRETATION}

1. A treaty shall be interpreted in good faith in accordance with the ordinary meaning to be given to the terms of the treaty in their context and in the light of its object and purpose.

2. The context for the purpose of the interpretation of a treaty shall comprise $[\ldots]$ the text, including its preamble and annexes $[\ldots]$

\section{Article 32. SUPPLEMENTARY MEANS OF INTERPRETATION}

Recourse may be had to supplementary means of interpretation, including the preparatory work of the treaty and the circumstances of its conclusion, in order to confirm the meaning resulting from the application of article 31 , or to determine the meaning when the interpretation according to article 31 :

(a) Leaves the meaning ambiguous or obscure; or

(b) Leads to a result which is manifestly absurd or unreasonable.

The Hague Judgments Convention should be given a uniform interpretation by national courts. Article 20 of the Convention provides that:

Article 20

\section{Uniform interpretation}

In the interpretation of this Convention, regard shall be had to its international character and to the need to promote uniformity in its application.

The best place for national courts to start in order to arrive at such uniform interpretation is the Explanatory Report on the Convention. The reason being that the Report is not just the views of the rapporteurs but rather their views as checked and amended by all the Members of the Conference who participated in the Diplomatic Session. The final version of the Explanatory Report is not available at the time of writing.

\footnotetext{
2 The Vienna Convention is available at https://treaties.un.org/doc/publication/unts/volume\%20 1155/volume-1155-i-18232-english.pdf (accessed 28 January 2020). See Beaumont (2009), pp. 9-62, especially pp. 22-33. The Vienna Convention is in force for 116 parties as at 28 January 2020, see https://treaties.un.org/Pages/ViewDetailsIII.aspx?src=TREATY\&mtdsg_no=XXIII-1\&chapt er $=23 \&$ Temp $=$ mtdsg $3 \&$ clang $=\_$en $($accessed on 28 January 2020).
} 
In addition, where the meaning of the Convention is not clear from its wording, including its purpose and context as revealed by the text of the Convention including its preamble, recourse may be had to the preparatory work of the treaty (see Arts. 31 and 32 of the Vienna Convention above). Therefore, national courts can find guidance in the documents available on the $\mathrm{HCCH}$ website or in the final Proceedings of the 22nd Session (not yet published) that record the negotiating history of the Convention. In the context of the meaning of the provisions in the Convention relating to how it can apply to States and those acting for States two of the most significant documents are Preliminary Document No. 5 of April 2019 and Information Document No. 6 of June 2019 reflecting the work of the Group dealing with those provisions. I had the privilege of chairing this Informal Working Group on Governments.

The rest of the article will focus on the specific provisions in the Judgments Convention relating to Governments.

\section{Articles 1(1) and 2(4) and (5)-Exclusion of Public Law and Non-interference with State Immunity}

Article 1

Scope

1. This Convention shall apply to the recognition and enforcement of judgments in civil or commercial matters. It shall not extend in particular to revenue, customs or administrative matters.

[...]

Article 2

Exclusions from scope

[...]

4. A judgment is not excluded from the scope of this Convention by the mere fact that a State, including a government, a governmental agency or any person acting for a State, was a party to the proceedings.

5. Nothing in this Convention shall affect privileges and immunities of States or of international organisations, in respect of themselves and of their property.

The consensus on the meaning of 'civil or commercial matters' will be reflected in the Explanatory Report on the Convention by Professors Garcimartín and Saumier. The draft of the explanatory report that was available to me at the time of writing correctly emphasised that 'civil or commercial matters' has to be given an autonomous treaty interpretation. It is not a reference to national or regional law interpretations of 'civil or commercial matters'. Neither the nature of the court that gave, nor the legal status of the parties to the proceedings that led to, the judgment that is sought to be enforced determines whether the judgment concerns civil or commercial matters. Instead, in the words of paragraph 33 of the draft available to me, the crucial issue is as follows: 
The key element distinguishing public law matters from 'civil or commercial' matters is whether one of the parties is exercising governmental or sovereign powers that are not enjoyed by ordinary persons.

The draft report also says that no distinction should be drawn between 'sovereign powers', 'governmental powers' and 'public powers'.

The rapporteurs also stress the need to give 'civil or commercial matters' the same meaning as in the Hague Choice of Court Convention 2005.

Another significant point of guidance from the draft explanatory report is the assertion that:

when a governmental agency is acting on behalf of private parties, such as consumers or investors, without that agency exercising [sovereign] powers or privileges, the Convention will also apply ${ }^{3}$

The draft explanatory report leaves open the difficult question of what constitutes a sovereign power or privilege that is not enjoyed by ordinary persons. It might be said that the ability of a government agency to act collectively on behalf of private parties-whether they are consumers or the victims of a cartel or anything elsedoes involve by definition sovereign power. Such agencies will often have resources from the public purse to do this task which purely private parties would have to fund themselves. Admittedly the funding issue can be more blurred than that because the private parties may in some legal systems be able to qualify for State funding for their actions through legal aid or attract private funding for a share of any damages awarded. But surely the government agency is still in a different position from a group of private parties funded by legal aid or by private funding. The government agency may well be complying with a statutory duty to do its work and the way it does it might be subject to judicial review. Therefore, it is exercising public powers in bringing the action on behalf of the parties and is not just accountable to those private parties as its clients (if it is accountable to them at all) it is accountable to the general public to fulfil its statutory duty. Therefore, on a strict construction of 'sovereign powers' all such actions by government agencies on behalf of private parties would fall outside 'civil or commercial matters'.

Ultimately national courts in countries where a judgment obtained by the efforts of such a government agency is sought to be enforced will have to analyse the powers of the agency in that case and determine whether it exercised sovereign powers or privileges that private parties do not have. The draft explanatory report by listing this example seems to imply that the inherent financial and institutional power of the government agency which acts collectively on behalf of private parties is not in and of itself enough to take the judgment outside of 'civil or commercial matters'. However, what is enough to do so is very much an open question.

\footnotetext{
3 The author amended the report to use the word 'sovereign' because it may be more likely to be the word used in the final version of the report.
} 
Once the draft explanatory report turns to Article 2(4) of the Convention it draws an interesting conclusion about its interpretation in the Judgments Convention from the existence of Article 19:

81. Unless a declaration under Article 19 is made, the Convention applies when a State or a governmental agency is acting as a private person, i.e., without exercising sovereign powers, and regardless of whether the public entity is the judgment creditor or the judgment debtor.

The draft report then pays homage to the long genesis of the Judgments Convention by taking guidance on Article 2(4) from where it was first negotiated in the failed Judgments Convention between 1992 and 2001 as recorded in the draft report on the failed Convention by Professors Nygh and Pocar:

Three core criteria are relevant to determining the application of the Convention to disputes involving State parties: (i) the conduct upon which the claim is based is conduct in which a private person can engage; (ii) the injury alleged is an injury which can be sustained by a private person; (iii) the relief requested is of a type available to private persons seeking a remedy for the same injury as the result of the same conduct.

It is regrettable that the draft explanatory report does not take more account of some suggested changes to an earlier version of it made by the Informal Working Group on Governments at the Diplomatic Session. Those suggestions reflected the consensus in the Group arrived at after careful and detailed discussion by many of the delegations to the Diplomatic Session. Furthermore, those suggestions were reported to the Diplomatic Session in an Information Document (No. 6 of June 2019) and were not opposed in the plenary. ${ }^{4}$

It was requested that the first part of paragraph 81 of the draft report quoted above should be modified to indicate that the assertions made there are not only subject to an Article 19 declaration but to 'the applicable rules on immunities'. This is a delicate matter because undoubtedly what is said in paragraph 81 as quoted above is correct about the interpretation of 'civil or commercial matters'. What the Informal Working Group wanted to clarify is that the Convention does not take a stance on the scope of State immunity. Indeed, as we will see shortly from paragraph 84 of the draft explanatory report's discussion of Article 2(5), the rapporteurs share that view. The Informal Working Group was anxious to avoid any misunderstanding caused by the part of paragraph 81 of the draft report quoted above. It would be accurate to say that in the absence of an Article 19 declaration cases fall within the scope of the Convention when a State or a governmental agency is 'acting as a private person' and not exercising sovereign powers. Indeed, it is technically correct to say that the Convention 'applies' even when the State addressed refuses to recognise and enforce such a judgment relying on State immunity which is preserved by Article

\footnotetext{
${ }^{4}$ See Minutes No. 15 at paras. 135-162. The concerns raised about the suggestions for the explanatory report did not relate to the suggestions in Info. Doc. No. 6 but rather about how to deal with State-owned enterprises in the report on Art. 19.
} 
2(5). But it would have respected the concerns of the Informal Working Group-and therefore more accurately reflected the intentions of the drafters of the Convention as evidenced by the negotiations in the Diplomatic Session-had the draft report clarified that the Convention might not have any effects in such a case because of the application of State immunity by the State addressed because State immunity is not subject to a uniform interpretation under the Convention due to the nature of the wording of Article 2(5). ${ }^{5}$

On a much more minor note the draft explanatory report as quoted in the second extract from paragraph 81 above might have graciously accepted the polite suggestion from the Informal Working Group to drop the word 'core'.

The draft explanatory report has quite a lot to say on Article 2(5) but only one non-controversial paragraph will be quoted here:

84. This paragraph of the Convention is a 'nil-effect clause' intended only to prevent the misinterpretation of paragraph 4. It has no implications for the meaning or scope of privileges or immunities under international law. The Convention has effect neither on State claims to jurisdictional immunity before the court of origin nor on claims to jurisdictional immunity or immunity from execution before the court of the requested State.

\section{Article 2(1)(n) and 2(1)(0)-Armed Forces and Law Enforcement}

\section{Article 2 \\ Exclusions from scope \\ 1. This Convention shall not apply to the following matters - [...]}

(n) activities of armed forces, including the activities of their personnel in the exercise of their official duties;

(o) law enforcement activities, including the activities of law enforcement personnel in the exercise of their official duties;

\footnotetext{
${ }^{5}$ See the relevant part of the introduction of Info. Doc. No. 6 of June 2019 to the plenary by the Chair of the Informal Working Group on Governments (the present writer) at para. 135 of the Minutes No. 15: 'the group reached a consensus on the [suggested amendment to what is now para. 81 of the draft explanatory report-then para. 71] clarifying that the applicable rules on immunities were relevant to the question of whether a State can be found liable under the Convention. He remarked that States can apply their interpretation of immunity law to decide whether a judgment should be recognised and enforced since Article 2(5) states that nothing in the Convention affects immunities of States.' Russia had warned me as Chair of the Informal Working Group that they would still have to table a working document seeking the deletion of Art. 2(4) that it and Argentina had been asking for in the Informal Working Group, see Working Document No. 76, but reassured me that if their proposal was not adopted by the plenary they would not block the consensus in the plenary on the current version of Art. 2(4) and (5). Russia proved true to their word. I had worked hard to persuade Argentina and Russia on this point. The Argentine delegation graciously accepted the compromise in the Informal Working Group that had given them Art. 2(1)(q). I had worked with the relevant Russian delegate for many years on this and other Hague projects and this had established mutual trust.
} 
The draft explanatory report available to me has the following to say on these provisions:

65. Sub-paragraph (n) covers judgments related to the activities of armed forces as such, but it specifically mentions that it includes the activities of their personnel 'in the exercise of their official duties'. Thus, any judgment against (or in favour of) the armed forces is excluded, whereas a judgment concerning their personnel is only excluded if it rules on a dispute arising from the exercise of their official duties. Thus, for example, a judgment on a civil claim against a soldier deriving from their personal activities, such as a purchase of a private vehicle or a car accident during a holiday trip, is covered by the Convention. Conversely, if the accident occurs in the context of a military exercise, any judgment against the individual soldier will be excluded. The term 'personnel' may also include civilians enrolled or employed by the armed forces: i.e., the relevant element is the activities they are carrying out, not their employment status.

66. Law enforcement activities. Sub-paragraph (o) excludes judgments related to law enforcement activities, including the activities of law enforcement personnel in the exercise of their duties. This exclusion is closely linked to the exclusion in sub-paragraph (n) and follows the same formulation, with an important difference. To avoid definitional disputes about whether a particular agency is a law enforcement entity, the exclusion refers to 'law enforcement activities' rather than a person or entity, like the armed forces. It typically covers bodies that carry out law enforcement activities, such as the police force or border control officers. Leaving aside this aspect, both provisions have many elements in common. As with sub-paragraph (n), most judgments regarding such activities would not be considered to fall within the 'civil or commercial' scope of the Convention but were included here to address potential divergences in interpretation of acta iure imperii under national law. The term 'personnel' includes any person carrying out official law enforcement activities irrespective of their employment status. And also, as with sub-paragraph (n), this exclusion has no implications for the rules on immunity and privileges which are entirely preserved under Article 2(5).

These two exclusions from scope may seem to simply confirm that the activities of law enforcement agencies or the armed forces, or the activities of a person working for the armed forces or a law enforcement agency who is engaged in their official duties, do not constitute 'civil or commercial matters' for the purposes of this Convention. Of course, it is not quite so simple as that. In many cases the exclusion in Article 2(1)(n) and (o) just confirms what is already excluded by Article 1(1). However, the exclusions in Article 2(1)(n) and (o) can take some matters that are within the scope of the Convention under Article 1(1) outside of the scope of the Convention. For example, some courts in States addressed may take the view that the armed forces or law enforcement agencies are engaged in the activities of the armed forces or law enforcement when they buy weapons for use by the armed forces or law enforcement agencies. Normally such public procurement of weapons 
would be a 'civil or commercial matter' as the purchase does not involve an exercise of public power-it is normally done in the commercial marketplace and the sellers may be commercial companies who might expect to be able to bring an action in contract against the armed forces or the law enforcement agency. Any judgment from such a contractual dispute may not circulate under the Hague Judgments Convention. If such a contract contained an exclusive choice of court agreement and the chosen court gave a judgment on a dispute between the armed forces or law enforcement agency and the commercial supplier of the weapons, then it would circulate under the Hague Choice of Court Convention 2005. Although that Convention also is limited to 'civil and commercial matters' it does not have either of the exclusions found in Article 2(1)(n) or (o) of the Judgments Convention.

\section{Article 2(1)(q)-Unilateral Sovereign Debt Restructuring}

Article 2

Exclusions from scope

1. This Convention shall not apply to the following matters -

$[\ldots]$

(q) sovereign debt restructuring through unilateral State measures.

This exclusion from scope was not discussed until the Diplomatic Session. Argentina shared its concerns about the risk that some courts might take a broad view of civil and commercial matters and include changes made to sovereign debt within it. States enter into many contracts with private persons or businesses who are willing to lend them money in exchange for repayment at a certain rate of interest. If a State gets into financial difficulties it will try to negotiate a change in the terms of the contract with the other party to it. If it succeeds, then in principle any judgment against that State obtained by the private person will be enforceable under the Judgments Convention as a civil or commercial matter. The risk that the exclusion from scope in Article 2(1)(q) addresses, is that some courts might still regard a judgment as falling within civil or commercial matters, where it enforces the original contractual agreement between the State and the private lender, even though the State had unilaterally changed the terms of the contract before the proceedings giving rise to the judgment had begun. Many would take the view that such unilateral actions by a State are an exercise of its public powers and take the matter outside the scope of the Convention because it is not a civil or commercial matter. However, as uniform interpretation of the Convention is not absolutely guaranteed by the terms of Article 20 of the Convention, the Diplomatic Session agreed by consensus to expressly remove any doubt on the matter and specifically exclude 'unilateral' State measures on 'sovereign debt restructuring'.

The draft explanatory report available to me inter alia says the following on this provision:

72. Sovereign debt restructuring. Sub-paragraph (q) excludes sovereign debt restructuring through unilateral State measures. The concept of 'sovereign debt 
restructuring' is taken from the resolutions of the United Nations on this matter which recognise the right of a sovereign State, in the exercise of its discretion, to design its macroeconomic policy, including restructuring its sovereign debt. [footnote says-See Resolution adopted by the General Assembly on 9 September 2014, 68/304, Towards the establishment of a multilateral legal framework for sovereign debt restructuring processes; Resolution adopted by the General Assembly on 29 December 2014, 69/247, Modalities for the implementation of resolution 68/304; and Resolution adopted by the General Assembly on 10 September 2015, 69/319, Basic Principles on Sovereign Debt Restructuring Processes.] The word 'unilateral' is however included to reduce the scope of the exclusion. It covers compulsory measures of debt restructuring adopted by a State, i.e. measures that were not provided for in the initial borrowing terms and are adopted without or against the consent of the investors. Conversely, measures of debt restructuring adopted in accordance with the borrowing terms or that were freely negotiated with the investors are not covered by this exclusion. It is true that to a large extent unilateral measures of sovereign debt restructuring fall outside the scope of the Convention under Article 1(1); however, the Twenty-Second Session considered it appropriate to add an express exclusion of those matters to prevent any misinterpretation.

The draft explanatory report highlighted in a footnote that the issue has arisen in the EU where the Court of Justice of the European Union has given a clear preliminary ruling precisely on the question of whether unilateral sovereign debt restructuring falls within 'civil and commercial matters' for the purposes of the Brussels Ia Regulation ${ }^{6}$ in the Kuhn case. ${ }^{7}$ It seems helpful here to do what the report was not able to do and give an extended, edited quotation from the judgment in Kuhn:

$34[\ldots]$ the Court has held that, although certain actions between a public authority and a person governed by private law may come within the scope of [civil and commercial matters], it is otherwise where the public authority is acting in the exercise of its public powers (judgment of 15 February 2007, Lechouritou and Others, C-292/05, EU:C:2007:102, paragraph 31 and the case-law cited).

35 That applies, namely, to disputes resulting from the exercise of public powers by one of the parties to the case, as it exercises powers falling outside the scope of the ordinary legal rules applicable to relationships between private individuals (judgment of 15 February 2007, Lechouritou and Others, C-292/05, EU:C:2007:102, paragraph 34).

\footnotetext{
${ }^{6}$ Regulation (EU) No. 1215/2012 of the European Parliament and of the Council of 12 December 2012 on jurisdiction and the recognition and enforcement of judgments in civil and commercial matters [2012] OJ L 351/1-32.

${ }^{7}$ See Case C-308/17 Hellenische Republik v. Leo Kuhn, EU:C:2018:911. For a recent and authoritative account of the EU law on sovereign debt restructuring tackling some other issues than those raised here, see Poaires Maduro (2019), pp. 75-82.
} 
36 As regards the dispute in the main proceedings, it must, consequently, be established whether its origin stems from the acts of the Hellenic Republic, which arise from the exercise of public authority.

37 As stated by the Advocate General in points 62 et seq. of his Opinion, the manifestation of that exercise is the result of both the nature and the modalities of the changes to the contractual relationship between the Greek State and the holders of the securities at issue in the main proceedings [...]

38 Those securities, following the adoption of Law 4050/2012 by the Greek legislator and the retroactive introduction of a [collective action clause] CAC according to that law, were replaced by new securities with a much lower nominal value. Such a substitution of securities was not provided for in the initial borrowing terms or in the Greek law in force at the time that the securities subject to those conditions were issued.

39 Thus, that retroactive introduction of a CAC allowed the Hellenic Republic to impose on all of the holders of securities a substantial amendment to the financial terms of those securities, including on those that would have sought to oppose that amendment.

$[\ldots]$

42 It follows that, having regard to [...] the circumstances surrounding the adoption of Law 4050/2012, according to which the initial borrowing terms of the sovereign bonds at issue in the main proceedings were unilaterally and retroactively amended by the introduction of a CAC, and to the public interest objective that it pursues, the origin of the dispute in the main proceeding stems from the manifestation of public authority and results from the acts of the Greek State in the exercise of that public authority, in such a way that that dispute does not fall within 'civil and commercial matters' [...]

43 In those circumstances, the answer to the question referred is that [the] issue in the main proceedings, relating to an action brought by a natural person having acquired bonds issued by a Member State, against that State and seeking to contest the exchange of those bonds with bonds of a lower value, imposed on that natural person by the effect of a law adopted [...] by the national legislator, according to which those terms were unilaterally and retroactively amended by the introduction of a CAC allowing a majority of holders of the relevant bonds to impose that exchange on the minority, does not fall within 'civil and commercial matters' within the meaning of that article. ${ }^{8}$

\footnotetext{
8 The parts of the CJEU judgment in Kuhn that have been edited out of the quoted paragraphs relate to the requirement that the unilateral sovereign debt restructuring has to be an 'exceptional situation'. However, it seems that unilateral sovereign debt restructuring is only ever done in an "exceptional situation' because of the market consequences for the State of doing it. More importantly those sections of the CJEU's reasoning are excluded here because it is not the intention of the Diplomatic Session to restrict the exclusion from scope of the 2019 Hague Judgments Convention of unilateral sovereign debt restructuring to 'exceptional situations'. Such a requirement may be, according to the CJEU, part of EU internal law but it is not a requirement of the Hague Convention and therefore should not form part of CJEU
} 
People may legitimately ask why States should be able to unilaterally change their contractual relationships with the people they borrow money from and be immune from contractual remedies against them. The answer is that States pay a significant price for this in the sovereign debt markets. Such unilateral debt restructuring will make it much harder for any State that does it to borrow money on the markets. It is market discipline that ensures such unilateral State action is exceptional. In exceptional situations of financial crisis for a State it can be in the public interest to unilaterally restructure sovereign debts when the efforts at renegotiation of the terms with private lenders fail. Sadly, in those circumstances the private lenders often lose most of the money they lent to the State.

\section{Article 19 Declaration}

Article 19

Declarations with respect to judgments pertaining to a State

1. A State may declare that it shall not apply this Convention to judgments arising from proceedings to which any of the following is a party-

(a) that State, or a natural person acting for that State; or

(b) a government agency of that State, or a natural person acting for such a government agency.

The State making such a declaration shall ensure that the declaration is no broader than necessary and that the exclusion from scope is clearly and precisely defined. The declaration shall not distinguish between judgments where the State, a government agency of that State or a natural person acting for either of them is a defendant or claimant in the proceedings before the court of origin.

2. Recognition or enforcement of a judgment given by a court of a State that made a declaration pursuant to paragraph 1 may be refused if the judgment arose from proceedings to which either the State that made the declaration or the requested State, one of their government agencies or a natural person acting for either of them is a party, to the same extent as specified in the declaration.

The draft explanatory report is helpful in elucidating the meaning of the first paragraph of Article 19:

345. Scope-Parties. Paragraph 1 identifies the parties who can be included in the declaration. According to paragraph 1(a) and (b), these include the State itself and a government agency of that State. It also includes a natural person acting for either of them, but it does not include legal persons acting for the

Footnote 8 (continued)

interpretation of 'civil or commercial matters' when interpreting the 2019 Convention if the EU becomes a party to the Convention. The EU is actively considering becoming a party to the Convention as the issue is the subject of an impact assessment in early 2020. 
State, unless they qualify as government agencies. In all cases, paragraph 1 identifies parties who have the authority to exercise sovereign power, whether directly or in a delegated manner, generally or in a specific field, and natural persons acting for them, regardless of their employment status. For example, an entity charged with the enforcement of competition or consumer law would fall within paragraph 1 , regardless of whether it is integrated within the government structure or established as an autonomous and independent entity. Political sub-divisions of a State (including regional or local government) can also be included in a declaration under this provision. In essence, an Article 19 declaration can only be made in relation to a party whose functions are of a public nature even though it may also engage in commercial activities. The definitions are broad to capture the diversity of government structures and procedural definitions of juridical personality or capacity among States. But the last sentence of paragraph 1 requires that the declaration be no broader than necessary and that the exclusion from scope be clearly and precisely defined. As a result, a State making a declaration under Article 19 should identify which government agencies are covered by its declaration or the circumstances under which they would be included.

One of the difficult issues in drafting what is now Article 19 of the Convention was to exclude the possibility of States making such a declaration in relation to State-owned enterprises. It was clear that many States did not want the Convention to permit States to declare that the normal commercial activities of a State-owned enterprise could be covered by an Article 19 declaration. ${ }^{9}$ They feared that this would create an economic imbalance in that States which own entities engaged in commercial activities could refuse to recognise or enforce judgments given against them in other Contracting States because they had declared those activities of that entity to fall within the scope of the declaration. In order to avoid this the Diplomatic Session amended Article 19, as it was in square bracketed form in the draft Convention prepared by the Special Commission, so that it no longer refers at all to State entities but rather only to State agencies with the common understanding that a State-owned enterprise is not a State agency for this purpose. ${ }^{10}$

\footnotetext{
9 See the fact that there was broad support in the Informal Working Group on Governments in the preparation of the work of the Diplomatic Session that took place in Hong Kong, China to expressly exclude a declaration relating to State-owned enterprises, see Preliminary Document No. 5 of April 2019. See also the interventions recorded in the plenary of the Diplomatic Session in Minutes No. 6 at para. 24 (the chair of the informal working group), para. 37 (EU), para. 38 (USA), para. 42 (Switzerland), para. 43 (Canada), para. 44 (Norway), para. 45 (UK), and para. 48 (Australia).

10 Even though this was the common understanding in the Informal Working Group, China was reluctant to see it clarified in the explanatory report and after a discussion in the plenary the Chair of the plenary, David Goddard QC, ruled that the co-rapporteurs should be allowed to address the point by addressing the "'government entities" in respect of which a declaration could be made.' (see Minutes No. 15, paras. 154-162). The co-rapporteurs did not take up the Chair's invitation to do so in a clear way in the first draft of the explanatory report quoted above, but this is a situation where the final version of the report may be different in the light of the comments on the first version by the Members of the Hague Conference. It is worth noting that during the Diplomatic Session China worked hard to build consensus on the final version of the Convention. This was in large measure due to the quality of the leader of their delegation who had negotiated the Hague Choice of Court Convention 2005. His technical knowledge, and the
} 
However, there is a risk here that too much is made to turn on the difference between 'agency' and 'entity'. A better understanding of the Convention, perhaps, is to accept that a State 'agency' only covers a body that has as its 'primary purpose' the conduct of public law work, i.e. work for which it has special powers over and above other bodies to work for the public good. So, if a State owns a company that primarily sells cars but also has a role in setting safety standards for cars in that State an Article 19 declaration cannot be made in relation to that company. Any foreign judgment against that body concerning its role as a regulator of car safety standards would fall outside the scope of the Convention as not being a civil or commercial matter (no declaration is necessary for that). However, if the foreign judgment pertains to the commercial activities of the body in selling cars then the judgment falls within the scope of the Convention and cannot be taken outside of the scope of the Convention by a declaration under Article 19 as such a declaration is ultra vires.

It has to be said that there is no way for other Contracting States to prevent a State from abusing the declaration system and applying it to State-owned enterprises. One of the strongest deterrents against a State behaving in this way is contained in Article 19 itself. The reciprocal nature of that provision means that judgments in favour of any State-owned enterprise in relation to its commercial activities given by a court in a State making the declaration will not be recognised and enforced in other Contracting States under the Convention.

An example of a State agency for whom an Article 19 declaration could lawfully be made is a Law Commission (a publicly appointed agency which is independent of Government but is set up to examine possible law reforms in the legal system it is responsible for-in the UK there is the Law Commission for England and Wales and the Scottish Law Commission for Scotland and there are many other Law Commissions in other Commonwealth countries - and to make recommendations for law reform to the relevant Governments and Parliaments). Law Commissions meet the primary purpose test. They are primarily engaged in a public law activity for which they have special powers - they are State funded, creatures of Statute, the Commissioners are judges and lawyers appointed for their excellence rather than government sympathy, and the Commission is charged with carrying out work suggesting law reform for the public good. Thus, although they are not Government agencies as they are completely independent of Government, they are State agencies for the purpose of Article 19 of the Convention. Although it is difficult to see why any State would do so it would be competent for a State to include the civil and commercial activities of a Law Commission within an Article 19 declaration so that any foreign judgment against the Law Commission relating to such activities (e.g. buying a stock of law reports or books from that jurisdiction) would not be recognised or enforced under the Convention. Perhaps a more rational declaration would be to exclude the

Footnote 10 (continued)

mutual trust established between him and a number of US and EU delegates who had been involved in both negotiations, were crucial in arriving at consensus. The most notable example of this being on the historic inclusion of judgments in private enforcement actions against cartels within the scope of the Convention, see Art. 2(1)(p). 
recognition or enforcement of any civil liability of a Law Commission found in a foreign judgment based on the description of that foreign country's laws in a document published by the Law Commission. The purpose of such comparative law work is not to write about foreign law in a way that should be relied upon authoritatively by anyone in that foreign country but rather to assist people in the country where the Law Commission is working to understand what alternative options there are to the law in that country and how those alternatives appear to work elsewhere in order to inform possible law reforms in the country where the Law Commission is based.

\section{Conclusion}

The Hague Judgments Convention is the latest in a long line of Hague Conventions to confine its scope to private law matters rather than public law matters by saying that it only applies to 'civil or commercial matters'. There is already quite a lot of material from national court decisions on the other Conventions, from Hague Conference Special Commissions reviewing those Conventions, from the Explanatory Reports on those Conventions and from doctrinal analysis. All of that material can be relevant to ascertaining the meaning of 'civil or commercial matters' in the Judgments Convention but care should be used to ensure that any such interpretation is consistent with the Explanatory Report on the Judgments Convention and with the preparatory work on that Convention.

The other area where the Convention is consistent with a previous Hague Convention is in the repetition of what is stated in its sister Convention, Hague Choice of Court Convention 2005, in Article 2(4) and (5). In this context the interpretation of those provisions can be best ascertained by reading the explanatory report on the 2005 Convention by Professors Hartley and Dogauchi ${ }^{11}$ as well as the explanatory report on the 2019 Convention by Professors Garcimartín and Saumier.

The Judgments Convention has some innovative exclusions from scope. Those relating to the armed forces and law enforcement agencies take even private law disputes relating to the activities of those bodies outside of the scope of the Convention. However, this should not lead to it being assumed that such private law disputes leading to a judgment in a court exclusively chosen by the parties in a choice of court agreement fall outside the scope of the Hague Choice of Court Convention 2005. The exclusion for unilateral sovereign debt restructuring makes sure that those matters are outside of scope. However, a correct interpretation of 'civil or commercial matters' arrives at the same result.

Finally, the Convention, in Article 19, has an innovative declaration system permitting States to take certain types of private law judgments outside the scope of the Convention. This can be done in relation to central, regional and local government, for government agencies and for natural persons acting for the government or a government agency. However, it is clear from the text of the Convention and from the

\footnotetext{
11 Available at https://www.hcch.net/en/publications-and-studies/details4/?pid=3959 (accessed 29 January 2020).
} 
preparatory work on it that State-owned enterprises (i.e. enterprises engaging primarily in civil or commercial activities) cannot be covered by the declaration. One State during the negotiations was anxious not to highlight this point in relation to State-owned enterprises but even it did not disagree with the policy conclusion that a declaration should not cover the commercial activities of a State-owned enterprise. This article has argued that the correct interpretation of Article 19, to be faithful to the intention of the drafters, would be to only permit a declaration for a 'government agency' when it is a body that has as its 'primary purpose' the conduct of public law work, i.e. work for which it has powers, that private persons do not have, to seek the public good.

The fact that a consensus was obtained on the Judgments Convention in the Diplomatic Session is a huge cause for celebration after 27 years of work (23 on my part) and, as always, one of the main reasons this happened was because of mutual trust between experts built up over a long period of time, or even after a short time, where the people concerned showed integrity and flexibility.

Open Access This article is licensed under a Creative Commons Attribution 4.0 International License, which permits use, sharing, adaptation, distribution and reproduction in any medium or format, as long as you give appropriate credit to the original author(s) and the source, provide a link to the Creative Commons licence, and indicate if changes were made. The images or other third party material in this article are included in the article's Creative Commons licence, unless indicated otherwise in a credit line to the material. If material is not included in the article's Creative Commons licence and your intended use is not permitted by statutory regulation or exceeds the permitted use, you will need to obtain permission directly from the copyright holder. To view a copy of this licence, visit http://creativecommons.org/licen ses/by/4.0/.

\section{References}

Beaumont P (2009) Reflections on the relevance of public international law to private international law treaty making. Hague Recueil des Cours 340:9-62

Poiares Maduro M (2019) EU law and sovereign debt relief. In: Lenaerts K et al (eds) An ever-changing Union? Perspectives on the future of EU law in honour of Allan Rosas. Hart, Oxford, pp 75-82

Publisher's Note Springer Nature remains neutral with regard to jurisdictional claims in published maps and institutional affiliations. 